\title{
KINETICS OF OXIDATION OF D-ARABINOSE AND D-XYLOSE BY VANADIUM (V) IN THE PRESENCE OF MANGANESE II AS HOMOGENEOUS CATALYST
}

\author{
ODEBUNMI E.O. ${ }^{a}$, OGUNLAJA A.S. ${ }^{b}$ AND OWALUDE S.O. ${ }^{a}$ \\ ${ }^{a}$ Department of Chemistry, University of Ilorin, P.M.B. 1515, Ilorin, Nigeria. \\ ${ }^{b}$ Department of Chemical Sciences, Bells University of Technology, PMB 1015, Ota, Ogun State, Nigeria
}

(Received: March 5, 2009 - Accepted: June 3, 2010)

\begin{abstract}
Kinetics of oxidation of D-arabinose and D-Xylose by acidic solution of Vanadium (V) ions in the presence of manganese (II) has been reported. First-order dependence of the reaction rate was observed on [sugars] and $\left[\mathrm{H}^{+}\right]$at low concentrations throughout the oxidation reaction and a zeroth-order dependence on [sugar] and $\left[\mathrm{H}^{+}\right]$was observed at high concentrations. First-order kinetics with respect to [Mn (II)] was also observed throughout the oxidation for both sugars. The effect of $\mathrm{Cl}^{-}$concentration was found to be negligible. The reaction rates increases with the ionic strength of the medium. Various activation parameters were evaluated and provide further support to the proposed mechanism. Formic acid was reported as one of the oxidation products of the sugars.
\end{abstract}

Keywords: Kinetics; Vanadium (V); oxidation; Arabinose; Xylose; Manganese(II) chloride catalysis; Perchloric acid.

\section{INTRODUCTION}

The biological and economic importance of carbohydrates has been largely responsible for the interest in the study of their bio-chemical and physiochemical properties and reactivities. Aldoses are important for the understanding of carbohydrate metabolism because they undergo a wide variety of reactions and give rise to different products. Studies have been carried out on the structural elucidation, chemical degradation and oxidation reactions of various sugars likewise the catalytic oxidation of sugars have also been reported in both acidic and alkaline media using oxidants such as transition metal ions, inorganic acids, organometallic complexes and enzymes [1-9].

Vanadium is a trace transition metal with relevant biological properties. In recent years there has been extensive interest in the chemistry of vanadium complexes [20]. Vanadium is present as Vanadium (III) in the blood cells of certain marine invertebrates and it is formed as a reduction of Vanadium (V), the oxidation mechanisms of biologically important substances by vanadium (V) have been studied in detail because of their relevance in bio-inorganic chemistry [21].

Recently Mn (II) was reported to catalyze the oxidation of paracetamol and also reported to catalyze Xylose and Arabinose in chromium VI [10, 22].

In view of biological importance of reducing sugars and also in view of the fact that little or no information is available on Mn (II)-catalyzed oxidation of xylose and arabinose using $\mathrm{V}(\mathrm{V})$ as oxidants in acidic medium, the present study has been undertaken.

The aim of this present study is to determine the kinetic parameters of the catalysed reaction using Mn (II) from which a suitable reaction mechanism for the oxidation of reducing sugars under investigation will be proposed and the rate law derived also Activation parameters of both the catalyzed reaction and the uncatalyzed reaction would be compared to confirm if catalysis has occured .

\section{EXPERIMENTAL}

All chemicals were of analytical reagent grade and were used as received. Vanadium (V) (BDH) was prepared by dissolving $3 \mathrm{~g}$ of $\mathrm{NH} \mathrm{VO}$ in $40 \mathrm{~cm}^{3}$ of $2 \mathrm{M} \mathrm{NaOH}$ and $80 \mathrm{~cm}^{3}$ of $1 \mathrm{M} \mathrm{H}_{2} \mathrm{SO}_{4}$ added to the mixture. A yellow solution indicates $\mathrm{V}(\mathrm{V})$ [12], in preparation of the required concentration dilution factor was employed and its concentration was checked iodometrically. Solution of $\mathrm{MnCl}_{2}$ (Uchem limited) was prepared by dissolving the sample in known strength of very dilute hydrochloric acid $(0.001 \mathrm{M})$. The standard solution of arabinose and xylose (A.R. grade) were freshly prepared with doubly distilled water. The standard solution of $\mathrm{HClO}_{4}$ (E. Merck) was used to maintain the required acidity. $\mathrm{KCl}$ (Analar) was prepared by dissolving its required amount in doubly distilled water to fix the $\mathrm{Cl}^{-}$ion concentration and $\mathrm{NaClO}_{4}$ (Analar) was used to maintain the required ionic strength of the medium.

\section{Kinetic Measurements}

Appropriate quantities of the solutions of $\mathrm{V}(\mathrm{V}), \mathrm{HClO}_{4}, \mathrm{MnCl}_{2}, \mathrm{KCl}$ and $\mathrm{NaClO}_{4}$ were placed in separate glass vessels and kept for at least one hour in a thermo stated water bath after reaching the temperature of $40{ }^{\circ} \mathrm{C}$, the calculated amount of each reaction mixture were then added together into a particular glass vessel followed by the requisite amount of double-distilled water mixed together. The reaction mixture was then placed in a thermo stated water bath maintained at constant temperature of $40^{\circ} \mathrm{C}\left( \pm 0.5^{\circ} \mathrm{C}\right)$ and the reaction was initiated by adding the requisite amount of oxidant solution placed separately in the same bath. Progress of the reaction was followed by estimating the decrease in the absorbance of $\mathrm{V}(\mathrm{V})$ spectrophotometrically.

\section{RESULTS AND DISCUSSION}

The progress of the reaction was followed by measuring the decrease in absorbance of the vanadium $(\mathrm{V})$ ions at regular time interval, using a UNISPEC SM7504UV spectrophotometer. The pseudo-first-order rate constants $\left(\mathrm{k}_{\mathrm{obs}}\right)$ were determined from the linear portion of the plots of log (absorbance) versus time. [16]. The effect of the variations are shown in tables I and II below.

It was also observed that an increase in $\left[\mathrm{HClO}_{4}\right]\left(0.03-0.57 \mathrm{~mol} \mathrm{dm}^{-3}\right)$ in the reaction mixture results to an increase in the rate of reaction, thereby indicating a positive effect of $\left[\mathrm{H}^{+}\right]$on the system, but tends to zero order at a higher concentration (Table-I).

$\mathrm{V}(\mathrm{V})$ were varied at a concentration range of $1.0-8.0 \times 10^{-3} \mathrm{~mol} \mathrm{dm}^{-3}$, the rate of the reaction increases with an increase in oxidant concentration. Table II.

First order kinetics with respect to Xylose and Arabinose (from $0.2-2.2$ x $10^{-2} \mathrm{~mol} \mathrm{dm}^{-3}$ ), while a zero-order was observed at higher concentrations (Table-I)

The reaction follows first-order kinetics with respect to [Mn (II)] (1.0 $11.0 \times 10^{-4} \mathrm{~mol} \mathrm{dm}^{-3}$ ) indicating that the reaction is Mn (II) dependent (TableII).

$\left[\mathrm{NaClO}_{4}\right]\left(0.05-0.25 \mathrm{~mol} \mathrm{dm}^{-3}\right)$ the positive effect indicates that the reactions take place between ions of similar charges [18] (Table-II).

It was reported that the rate of the reaction has no effect on the $\left[\mathrm{Cl}^{-}\right]$. 
Table I: Effect of variation of [Sugars] and $\left[\mathrm{HClO}_{4}\right]$ of the medium on pseudo first- order rate constant $\mathrm{k}_{\mathrm{obs}}$ in the oxidation of arabinose and xylose at $40^{\circ} \mathrm{C}$.

\begin{tabular}{|c|c|c|c|}
\hline \multirow{2}{*}[\mathbf{HClO}_{\mathbf{4}}]{$\mathbf{M}$} & \multirow{2}{*}{ [Sugar] $\mathbf{M}$} & \multicolumn{2}{|c|}{$\mathbf{k}_{\text {obs }} \times \mathbf{1 0}^{\mathbf{5}} \mathbf{s}^{\mathbf{- 1}}$} \\
\cline { 3 - 4 } & & $\mathbf{D}-$ arabinose & $\mathbf{D}-\mathbf{x y l o s e}$ \\
\hline & & & \\
0.03 & 0.01 & 0.17 & 0.09 \\
0.15 & 0.01 & 0.68 & 0.36 \\
0.27 & 0.01 & 0.98 & 0.40 \\
0.33 & 0.01 & 1.12 & 0.50 \\
0.39 & 0.01 & 1.32 & 0.60 \\
0.45 & 0.01 & 1.47 & 0.80 \\
0.51 & 0.01 & 1.53 & 1.20 \\
0.57 & 0.01 & 1.55 & 1.30 \\
0.15 & 0.01 & 1.59 & 1.40 \\
0.15 & 0.002 & 1.21 & 0.35 \\
0.15 & 0.008 & 1.63 & 0.83 \\
0.15 & 0.010 & 2.15 & 1.33 \\
0.15 & 0.012 & 2.72 & 1.67 \\
0.15 & 0.014 & 3.19 & 1.80 \\
0.15 & 0.016 & 3.55 & 2.17 \\
0.15 & 0.018 & 3.87 & 2.15 \\
0.15 & 0.02 & 3.92 & 2.22 \\
& 0.022 & 3.97 & 2.23 \\
\hline
\end{tabular}

Solution conditions: $[\mathrm{V}(\mathrm{V})]=1 \times 10^{-3} \mathrm{M},\left[\mathrm{MnCl}_{2}\right]=6 \times 10^{-4} \mathrm{M} ;[\mathrm{KCl}]$ $=5 \times 10^{-4} \mathrm{M} ;\left[\mathrm{NaClO}_{4}\right]=0.1 \mathrm{M}$.

Table II: Effect of variation of $\left[\mathrm{NaClO}_{4}\right]$ and $\left[\mathrm{MnCl}_{2}\right]$ of the medium on pseudo first- order rate constant $\mathrm{k}_{\mathrm{obs}}$ in the oxidation of arabinose and xylose at $40^{\circ} \mathrm{C}$.

\begin{tabular}{|c|c|c|c|c|}
\hline \multirow{2}{*}[\mathrm{NaClO}_{4}]{$\mathrm{M}$} & \multirow{2}{*}{$\begin{array}{l}{[\mathrm{V}(\mathrm{V})]} \\
\times 10^{-3} \mathrm{M}\end{array}$} & \multirow{2}{*}{$\begin{array}{c}{\left[\mathrm{MnCl}_{2}\right] \times 10^{-}} \\
{ }^{4} \mathrm{M}\end{array}$} & \multicolumn{2}{|c|}{$\mathrm{k}_{\mathrm{obh}} \times 10^{-5} \mathrm{~s}^{-1}$} \\
\hline & & & D-arabinose & D-xylose \\
\hline 0.05 & 1.0 & 6.0 & 0.65 & 0.50 \\
\hline 0.08 & 1.0 & 6.0 & 0.73 & 0.67 \\
\hline 0.12 & 1.0 & 6.0 & 0.86 & 0.83 \\
\hline 0.15 & 1.0 & 6.0 & 1.23 & 1.00 \\
\hline 0.16 & 1.0 & 6.0 & 1.36 & 1.17 \\
\hline 0.20 & 1.0 & 6.0 & 1.46 & 1.34 \\
\hline 0.25 & 1.0 & 6.0 & 1.58 & 1.78 \\
\hline 0.1 & 2.0 & 6.0 & 2.3 & 1.0 \\
\hline 0.1 & 3.0 & 6.0 & 3.6 & 1.5 \\
\hline 0.1 & 4.0 & 6.0 & 4.5 & 2.4 \\
\hline 0.1 & 5.0 & 6.0 & 5.8 & 3.2 \\
\hline 0.1 & 6.0 & 6.0 & 6.9 & 5.0 \\
\hline 0.1 & 7.0 & 6.0 & 8.4 & 6.8 \\
\hline 0.1 & 8.0 & 6.0 & 9.3 & 8.3 \\
\hline 0.1 & 1.0 & 1.0 & 0.38 & 0.30 \\
\hline 0.1 & 1.0 & 3.0 & 1.15 & 0.91 \\
\hline 0.1 & 1.0 & 5.0 & 1.85 & 1.41 \\
\hline 0.1 & 1.0 & 7.0 & 2.70 & 1.90 \\
\hline 0.1 & 1.0 & 9.0 & 3.45 & 2.80 \\
\hline 0.1 & 1.0 & 11.0 & 3.98 & 3.20 \\
\hline
\end{tabular}

Solution conditions: $[$ Sugar $]=1.00 \times 10^{-2} \mathrm{M}, \quad\left[\mathrm{HClO}_{4}\right]=0.15 \mathrm{M},[\mathrm{KCl}]$ $=5 \times 10^{-4} \mathrm{M}$

The reactions were further studied at four different temperatures, i.e. 40 , 50,60 and $70^{\circ} \mathrm{C}$ and the observed values of pseudo-first-order rate constant, $\mathrm{k}_{\mathrm{obs}}$ were utilized to calculate the activation parameters of the various sugars including their entropy of activation reported in Table III and IV. The Arrhenius activation energies, E, for the uncatalysed path were 98.83 and $99.90 \mathrm{kJmol}^{-1}$ for Xylose and Arabinose respectively, while the Arrhenius activation energies for the catalysed path were 44.52 and $45.16 \mathrm{kJmol}^{-1}$ for xylose and arabinose respectively. The wide difference in Activation energies of 54.31 and $53.84 \mathrm{k}$ $\mathrm{Jmol}^{-1}$ were observed for Xylose and Arabinose respectively indicating that the reaction is catalyzed [19].

Energy of activation and other activation parameters observed for the oxidation of D-arabinose and D-xylose at $40{ }^{\circ} \mathrm{C}$.
Table III: For the catalysed path.

\begin{tabular}{|c|c|c|c|c|c|c|}
\hline SUGARS & $\begin{array}{c}\mathrm{E}_{\text {act }} \\
\mathrm{kJmol}^{-1}\end{array}$ & $\begin{array}{c}\Delta \mathrm{H}^{\#} \\
\mathrm{kJmol}^{-1}\end{array}$ & $\begin{array}{c}\Delta \mathrm{S}^{\#} \\
\mathrm{Jmol}^{-} \\
{ }^{1} \mathrm{~K}^{-1}\end{array}$ & $\begin{array}{c}\Delta \mathrm{G}^{\#} \\
\mathrm{kJmol}^{-1}\end{array}$ & $\begin{array}{c}\mathrm{K}_{\text {obs }}\left(\mathrm{s}^{-1}\right) \\
\times 10^{5}\end{array}$ & $\begin{array}{c}\mathrm{A}\left(\mathrm{mol}^{-}\right. \\
\left.{ }^{2} \mathrm{dm}^{6} \mathrm{~s}^{-1}\right)\end{array}$ \\
\hline Xylose & 44.52 & 41.92 & -154.63 & 90.32 & 1.33 & $5.42 \times 10^{4}$ \\
\hline Arabinose & 45.16 & 42.55 & -150.48 & 89.65 & 2.15 & $8.93 \times 10^{4}$ \\
\hline
\end{tabular}

Table IV: For the uncatalysed path.

\begin{tabular}{|c|c|c|c|c|c|c|}
\hline SUGARS & $\begin{array}{c}\mathbf{E}_{\text {act }} \\
\mathbf{k J m o l}^{-1}\end{array}$ & $\begin{array}{c}\Delta \mathbf{H}^{\sharp} \\
\mathbf{k J m o l}^{-1}\end{array}$ & $\begin{array}{c}\Delta \mathbf{S}^{\sharp} \\
\mathbf{J m o l}^{-} \\
{ }^{1} \mathbf{K}^{-1}\end{array}$ & $\begin{array}{c}\Delta \mathbf{G}^{\sharp} \\
\mathbf{k J m o l}^{-1}\end{array}$ & $\begin{array}{c}\mathbf{k}_{\mathbf{s}}\left(\mathbf{s}^{-1}\right) \\
\times \mathbf{1 0}^{\mathbf{5}}\end{array}$ & $\begin{array}{c}\mathbf{A}\left(\mathbf{m o l}^{-}\right. \\
\left.{ }^{2} \mathbf{d m}^{\mathbf{6}} \mathbf{s}^{-1}\right)\end{array}$ \\
\hline Xylose & 98.83 & 96.23 & 8.34 & 93.62 & 0.85 & $1.76 \times 10^{13}$ \\
\hline Arabinose & 99.90 & 97.30 & 14.17 & 92.86 & 0.95 & $3.55 \times 10^{13}$ \\
\hline
\end{tabular}

Average linear regression coefficients, $r \geq 0.9$, were observed for all activation parameters.

\section{Polymerization test}

To test for the presence of free radicals in the reaction, $20 \%$ acryl amide solution was added to reaction mixtures containing the substrate and the Vanadium (V) solution and was placed in an inert atmosphere for 24 hours. When the reaction mixture was diluted with methanol a precipitate was formed in the reaction mixture. This confirms the formation of free radicals in the redox reactions under investigation.

\section{Stoichiometry and product analysis}

Reaction mixtures, in which the concentration of $\mathrm{V}(\mathrm{V})$ was in large excess of the reducing sugars, were kept in the presence of appropriate quantities of $\mathrm{KCl}, \mathrm{NaClO}_{4}, \mathrm{MnCl}_{2}$ and $\mathrm{HClO}_{4}$ at room temperature for 72 hours. Estimation of the unreacted $\mathrm{V}(\mathrm{V})$ showed that 1 mole of each sugar consumes 1 moles of $\mathrm{V}(\mathrm{V})$ for oxidation to take place on the assumption that all the sugars are consumed under this condition. Formic acid was confirmed as one of the products of oxidation of the two sugars using spot test [12].

$$
\begin{array}{ll}
\mathrm{V}_{2} \mathrm{O}_{5}+\mathrm{H}_{2} \mathrm{O}+\mathrm{C}_{5} \mathrm{H}_{10} \mathrm{O}_{5} \stackrel{\mathrm{Mn}(\mathrm{II}) / \mathrm{H}^{+}}{\longrightarrow} & \mathrm{HCOOH}+\mathrm{RCOOH}+\mathrm{V}_{2} \mathrm{O}_{4}+\mathrm{H}_{2} \mathrm{~g} \\
\text { Fhere, } \mathrm{R}=\mathrm{C}_{3} \mathrm{H}_{7} \mathrm{O}_{3} &
\end{array}
$$

Spectrophotometric evidence for the formation of complexes in the reactions under investigation

In order to prove the formation of a complex between the Sugars, V $(\mathrm{V})$ and $\mathrm{MnCl}_{2}$ a spectral graph is used. Comparisons were made between the spectrum recorded for the solution of $\mathrm{V}(\mathrm{V}), \mathrm{Mn}(\mathrm{II})$ and $\mathrm{H}^{+}$and spectra recorded for the solutions of $\mathrm{V}(\mathrm{V}), \mathrm{Mn}(\mathrm{II})$ and $\mathrm{H}^{+}$with two different concentrations of sugar, it was found that there is an increase in absorbance from 0.288 to 0.300 . This increase in absorbance with the increase in sugar and $\mathrm{V}(\mathrm{V})$ concentrations clearly indicates that there is a formation of complex species[Mn (II)--S--Cr (V)] [19]. 


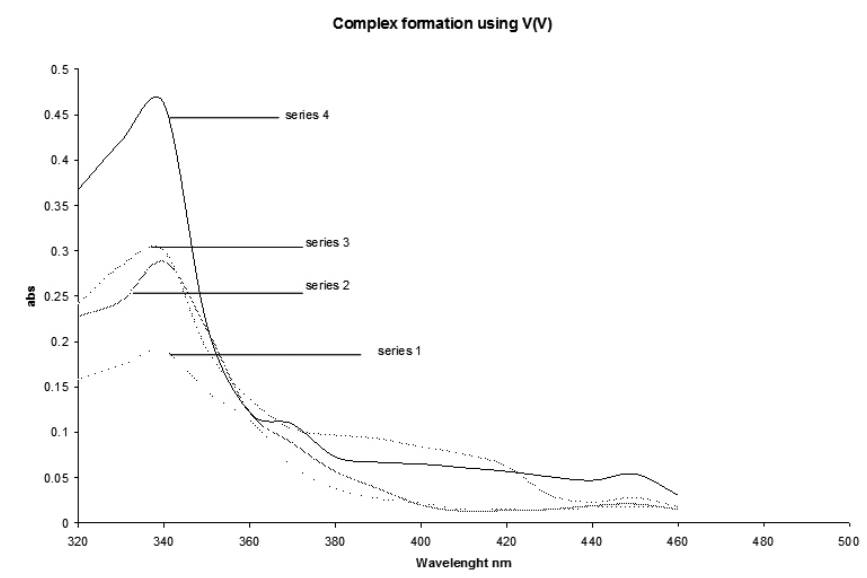

(1) $[\mathrm{V}(\mathrm{V})]=1.00 \times 10^{-3} \mathrm{~mol} \mathrm{dm}^{-3}$ and $\left[\mathrm{H}^{+}\right]=15.00 \times 10^{-2} \mathrm{~mol} \mathrm{dm}^{-3}$;

(2) $[\mathrm{Mn}$ (II) $]=7.63 \times 10^{-4} \mathrm{~mol} \mathrm{dm}^{-3},\left[\mathrm{H}^{+}\right]=15.00 \times 10^{-2} \mathrm{~mol} \mathrm{dm}^{-3}$ and $[\mathrm{V}$ (V)] $=1.00 \times 10^{-3} \mathrm{moldm}^{-3}$

(3) $[\mathrm{Mn}(\mathrm{II})]=7.63 \times 10^{-4} \mathrm{~mol} \mathrm{dm}^{-3},\left[\mathrm{H}^{+}\right]=15.00 \times 10^{-2} \mathrm{~mol} \mathrm{dm}^{-3}$ and $[\mathrm{V}(\mathrm{V})]$ $=1.00 \times 10^{-3} \mathrm{~mol} \mathrm{dm}^{-3}$

(4) $[\mathrm{Mn}(\mathrm{II})]=7.63 \times 10^{-4} \mathrm{~mol} \mathrm{dm}^{-3},\left[\mathrm{H}^{+}\right]=15.00 \times 10^{-2} \mathrm{~mol} \mathrm{dm}^{-3}$ and $[\mathrm{V}(\mathrm{V})]$ $=3.00 \times 10^{-3} \mathrm{~mol} \mathrm{dm}^{-3}$ and $[$ Sugar $]=1 \times 10^{-2} \mathrm{~mol} \mathrm{dm}^{-3}$.

\section{Mechanism}

From the present study between the oxidation of xylose and arabinose by $\mathrm{V}(\mathrm{V}$ ) in the presence of Mn (II) chloride as homogeneous catalyst, the entropy of activation was negative which suggest that the reaction proceeds through a hydride transfer process for complex formation. Thus when vanadate is acidified by perchloric acid the yellow pervanadyl ion, $\mathrm{VO}_{2}^{+}$, is formed as the initial species [14].

$$
\mathrm{VO}_{3}^{-}+2 \mathrm{H}^{+} \rightleftharpoons \mathrm{VO}_{2}^{+}+\mathrm{H}_{2} \mathrm{O}
$$

This may exist in hydrated form $\mathrm{V}(\mathrm{OH})_{4}^{+}[15]$. In stronger perchloric acid $\left(\mathrm{H}^{+}>2 \mathrm{M}\right)$ the species becomes protonated to form $\mathrm{VO}(\mathrm{OH})^{2+}[13]$.

\section{Reaction scheme}

A reaction mechanism based on the observed kinetic results and the spectral information collected for the formation of complex is as proposed in the reaction scheme below: [17]

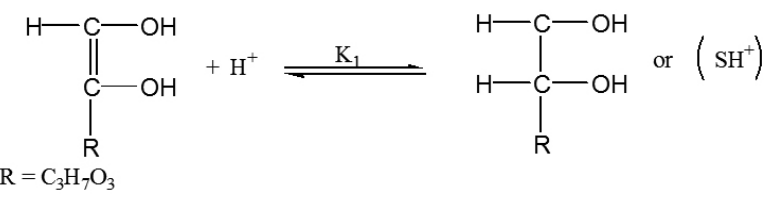

Where $\mathrm{SH}^{+}$represent the protonated form of the sugars.

The protonated sugar then reacts with the catalyst Mn(II), according to the equation(3) below to give the first complex labelled $\mathrm{C}_{1}$.

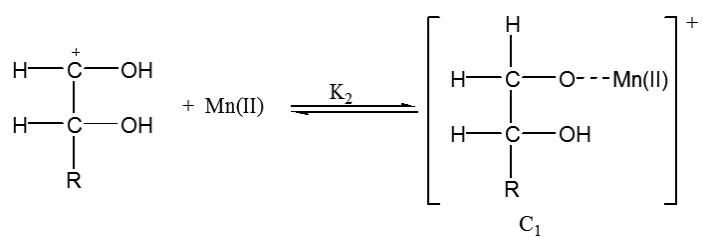

The positively charged complex then reacts further with the protonated Vanadium in the slow and rate determining step.

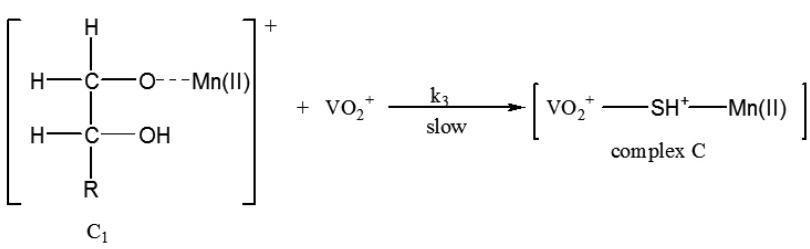

Equation 4 is supported by the positive effect of addition of sodium perchlorate on the rate of the reactions and indication that reactions take place between ions of similar charges [18]. The lower aldose undergoes further oxidation with the protonated chromic acid to yield the Erythronic acid.

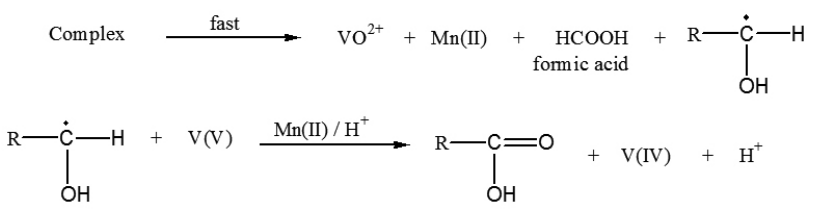

From the proposed mechanism, the rate of the reaction in terms of decrease in the concentration of $\mathrm{V}(\mathrm{V})$ was derived as;

$$
\frac{-\mathrm{d}\left[\mathrm{VO}_{2}^{+}\right]}{\mathrm{dt}}=\mathrm{k}_{3}[\mathrm{C}]\left[\mathrm{VO}_{2}^{+}\right]
$$

From the reaction mechanism the total $\mathrm{Mn}(\mathrm{II})$ i.e. $\mathrm{Mn}(\mathrm{II})_{\mathrm{T}}$ is given below:

$$
\begin{aligned}
& \mathrm{Mn}(\mathrm{II})_{\mathrm{T}}=\mathrm{Mn}(\mathrm{II})+\mathrm{C} \\
& \text { where } \mathrm{Mn}(\mathrm{II})=\mathrm{Mn}(\mathrm{II})_{\mathrm{T}}-\mathrm{C} \\
& \mathrm{K}_{1}[\mathrm{~S}]\left[\mathrm{H}^{+}\right]=\left[\mathrm{SH}^{+}\right]
\end{aligned}
$$

Substituting equation 7 into the equation below:

$$
\begin{aligned}
\mathrm{K}_{2} & =\frac{\mathrm{C}}{\left[\mathrm{SH}^{+}\right][\mathrm{Mn}(\mathrm{II})]} \\
\mathrm{K}_{2} & =\frac{\mathrm{C}}{\mathrm{K}_{1}[\mathrm{~S}]\left[\mathrm{H}^{+}\right][\mathrm{Mn}(\mathrm{II})]}
\end{aligned}
$$

Making the complex 'C" subject of the formulae;

$$
\begin{aligned}
& \mathrm{C}=\mathrm{K}_{2} \mathrm{~K}_{1}[\mathrm{~S}]\left[\mathrm{H}^{+}\right][\mathrm{Mn}(\mathrm{II})] \\
& \left.\mathrm{C}=\mathrm{K}_{2} \mathrm{~K}_{1}[\mathrm{~S}]\left[\mathrm{H}^{+}\right][\mathrm{Mn}(\mathrm{II})]_{\mathrm{T}}-\mathrm{C}\right] \\
& \mathrm{C}=\mathrm{K}_{2} \mathrm{~K}_{1}[\mathrm{~S}]\left[\mathrm{H}^{+}\right][\mathrm{Mn}(\mathrm{II})]_{\mathrm{T}}-\mathrm{K}_{2} \mathrm{~K}_{1}[\mathrm{~S}]\left[\mathrm{H}^{+}\right] \mathrm{C} \\
& \mathrm{C}=\frac{\mathrm{K}_{2} \mathrm{~K}_{1}[\mathrm{~S}]\left[\mathrm{H}^{+}\right][\mathrm{Mn}(\mathrm{II})]_{\mathrm{T}}}{1+\mathrm{K}_{2} \mathrm{~K}_{1}[\mathrm{~S}]\left[\mathrm{H}^{+}\right]}
\end{aligned}
$$

Substituting eq. 8 into eq. 6 gives;

$$
\text { Rate }=\frac{-\mathrm{d}\left[\mathrm{VO}_{2}^{+}\right]}{\mathrm{dt}}=\frac{\mathrm{k}_{3} \mathrm{~K}_{2} \mathrm{~K}_{1}[\mathrm{~S}]\left[\mathrm{H}^{+}\right]\left[\mathrm{VO}_{2}^{+}\right][\mathrm{Mn}(\mathrm{II})]_{\mathrm{T}}}{1+\mathrm{K}_{2} \mathrm{~K}_{1}[\mathrm{~S}]\left[\mathrm{H}^{+}\right]}
$$

Inverse of the reaction gives;

$$
\mathrm{Mn}(\mathrm{II})_{\mathrm{T}} * \frac{1}{\text { Rate }}=\frac{1}{\mathrm{k}_{3} \mathrm{~K}_{2} \mathrm{~K}_{1}[\mathrm{~S}]\left[\mathrm{H}^{+}\right]\left[\mathrm{VO}_{2}^{+}\right]}+\frac{1}{\mathrm{k}_{3}\left[\mathrm{VO}_{2}^{+}\right]}
$$

From the double reciprocal plot of the graph $\mathrm{Mn}$ (II)/rate against 1/[S] and $\mathrm{Mn}(\mathrm{II}) /$ rate against $1 /\left[\mathrm{H}^{+}\right]$the values of $\mathrm{k}_{3} \mathrm{~K}_{2} \mathrm{~K}_{1}$ and $\mathrm{k}_{3}$ were obtained as the slope and intercept respectively. From the respective plots of the data a straight line was obtained with a positive intercept which confirms the validity of equation (10). 


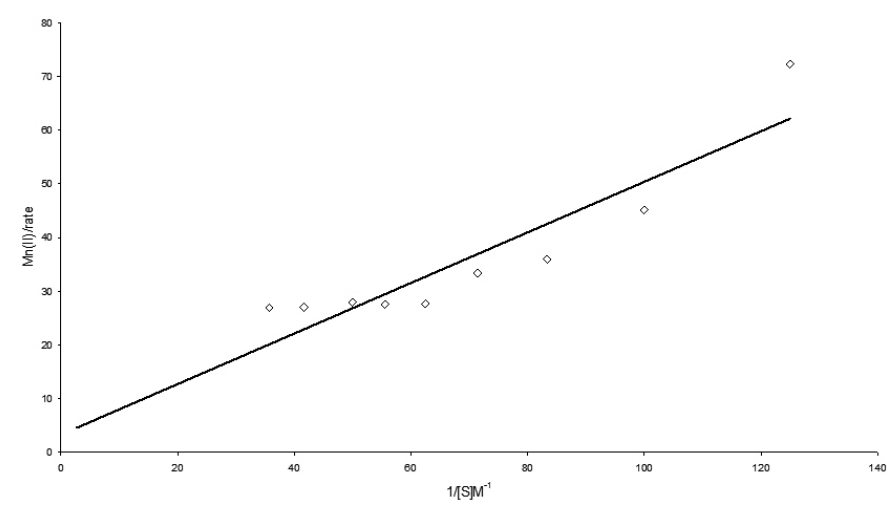

Fig. I: Plot of $\mathrm{Mn}(\mathrm{II})_{\mathrm{T}} / \mathrm{k}_{\text {obs }}$ against $1 /[$ xylose $]$ at $40^{\circ} \mathrm{C}$. $[\mathrm{V}(\mathrm{V})]=1 \times 10^{-3}$ $\mathrm{M},\left[\mathrm{MnCl}_{2}\right]=6 \times 10^{-4} \mathrm{M} ;[\mathrm{KCl}]=5 \times 10^{-4} \mathrm{M} ;\left[\mathrm{NaClO}_{4}\right]=0.1 \mathrm{M},\left[\mathrm{HClO}_{4}\right]=0.15 \mathrm{M}$

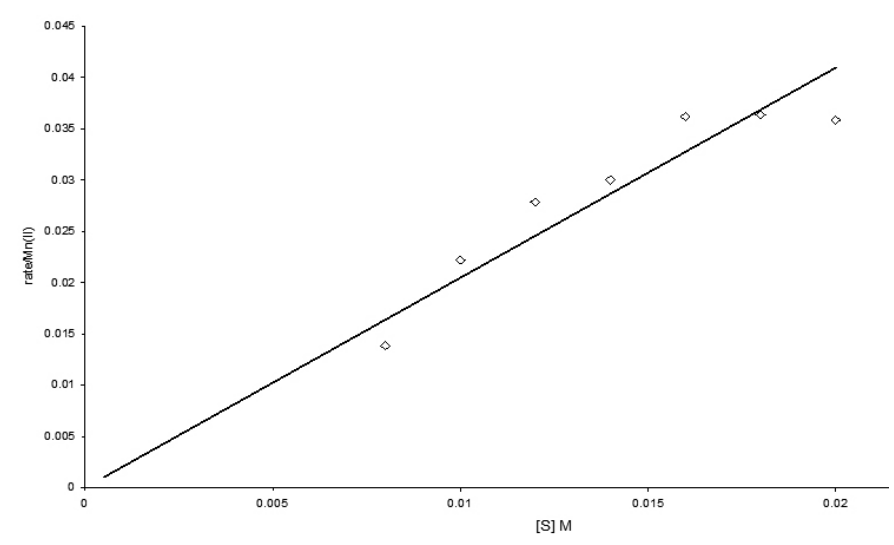

Fig. II. Plot of rate $/ \mathrm{Mn}(\mathrm{II})_{\mathrm{T}}$ against $[$ xylose $]$ at $40^{\circ} \mathrm{C}$. [V (V)] $=1 \times 10^{-3}$ $\mathrm{M},\left[\mathrm{MnCl}_{2}\right]=6 \times 10^{-4} \mathrm{M} ;[\mathrm{KCl}]=5 \times 10^{-4} \mathrm{M} ;\left[\mathrm{NaClO}_{4}\right]=0.1 \mathrm{M},\left[\mathrm{HClO}_{4}\right]=0.15 \mathrm{M}$.

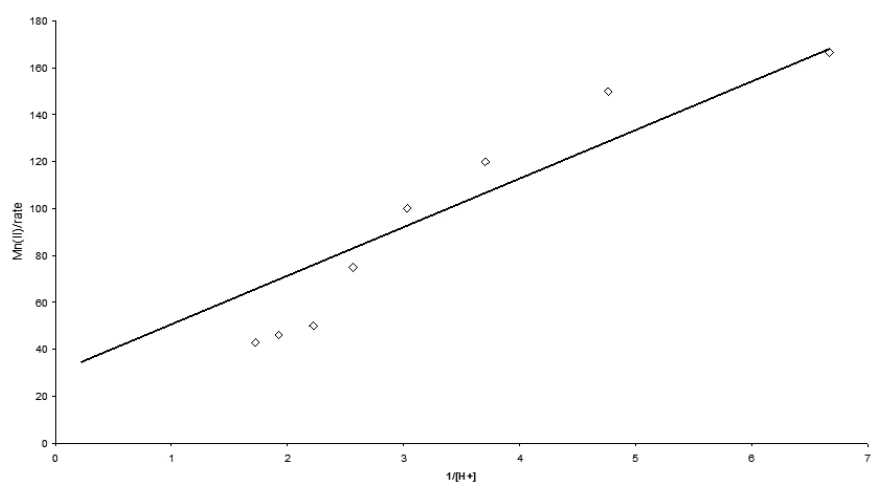

Fig. III. Plots of $\mathrm{Mn}(\mathrm{II})_{\mathrm{T}} / \mathrm{k}_{\mathrm{obs}}$ against $1 /\left[\mathrm{H}^{+}\right]$for xylose at $40^{\circ} \mathrm{C}$ : [xylose $]=0.01 \mathrm{M}[\mathrm{V}(\mathrm{V})]=1 \times 10^{-3} \mathrm{M},\left[\mathrm{MnCl}_{2}\right]=6 \times 10^{-4} \mathrm{M} ;[\mathrm{KCl}]=5 \times 10^{-4} \mathrm{M}$; $\left[\mathrm{NaClO}_{4}\right]=0.1 \mathrm{M}$

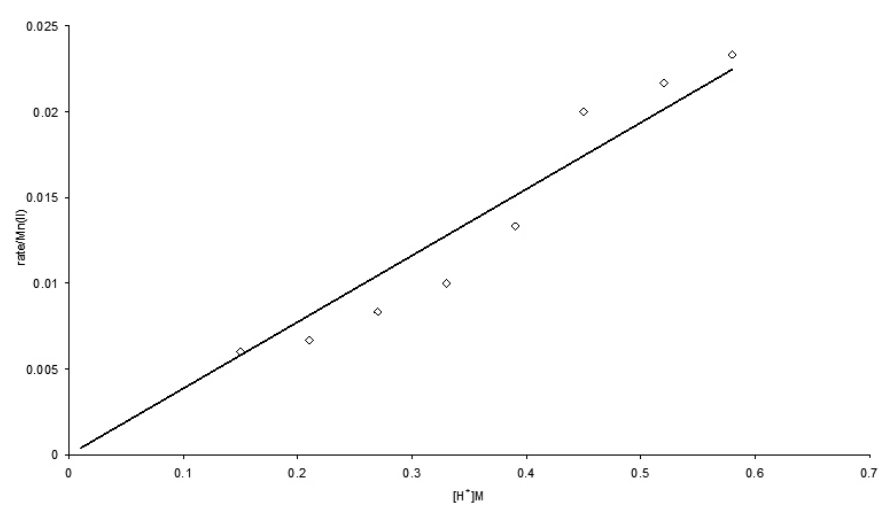

Fig.IV.Plot of rate $/ \mathrm{Mn}(\mathrm{II})_{\mathrm{T}}$ against $\left[\mathrm{H}^{+}\right]$for xylose at $40^{\circ} \mathrm{C}$. [xylose $]=0.01 \mathrm{M}$, $[\mathrm{V}(\mathrm{V})]=1 \times 10^{-3} \mathrm{M},\left[\mathrm{MnCl}_{2}\right]=6 \times 10^{-4} \mathrm{M} ;[\mathrm{KCl}]=5 \times 10^{-4} \mathrm{M} ;\left[\mathrm{NaClO}_{4}\right]=0.1 \mathrm{M}$

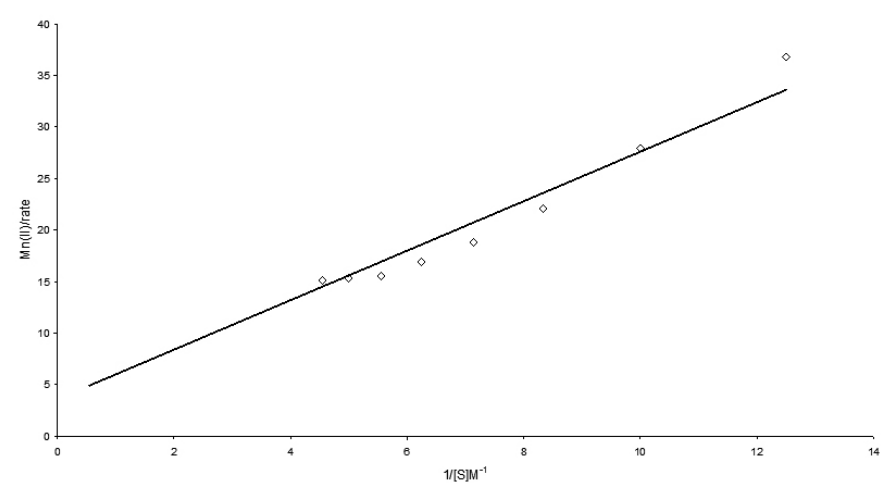

Fig.V. Plot of $\mathrm{Mn}(\mathrm{II})_{\mathrm{T}} /$ rate against $1 /[$ arabinose $]:[\mathrm{V}(\mathrm{V})]=1 \times 10^{-3} \mathrm{M}$, $\left[\mathrm{MnCl}_{2}\right]=6 \times 10^{-4} \mathrm{M} ;[\mathrm{KCl}]=5 \times 10^{-4} \mathrm{M} ;\left[\mathrm{NaClO}_{4}\right]=0.1 \mathrm{M},\left[\mathrm{HClO}_{4}\right]=0.15 \mathrm{M}$.

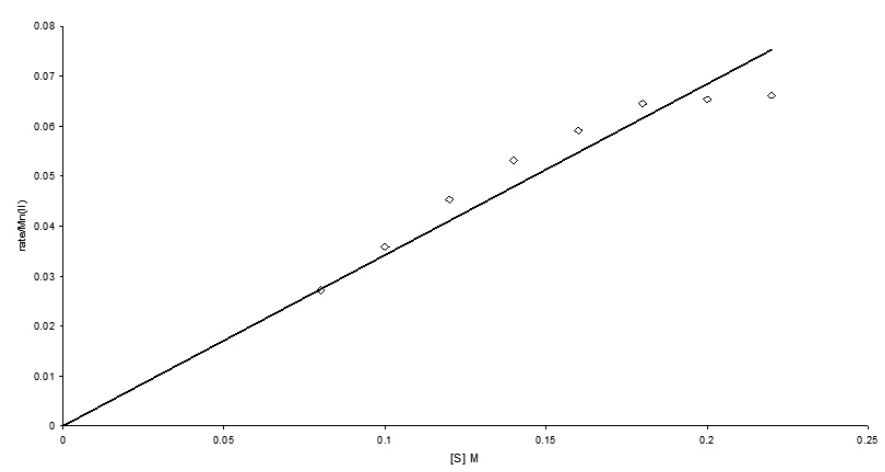

Fig.VI. plot of rate/Mn(II) $)_{\mathrm{T}}$ against $1 /[$ arabinose $]$ at $40^{\circ} \mathrm{C}[\mathrm{V}(\mathrm{V})]=1 \times 10^{-3}$ $\mathrm{M},\left[\mathrm{MnCl}_{2}\right]=6 \times 10^{-4} \mathrm{M} ;[\mathrm{KCl}]=5 \times 10^{-4} \mathrm{M} ;\left[\mathrm{NaClO}_{4}\right]=0.1 \mathrm{M},\left[\mathrm{HClO}_{4}\right]=0.15 \mathrm{M}$. 


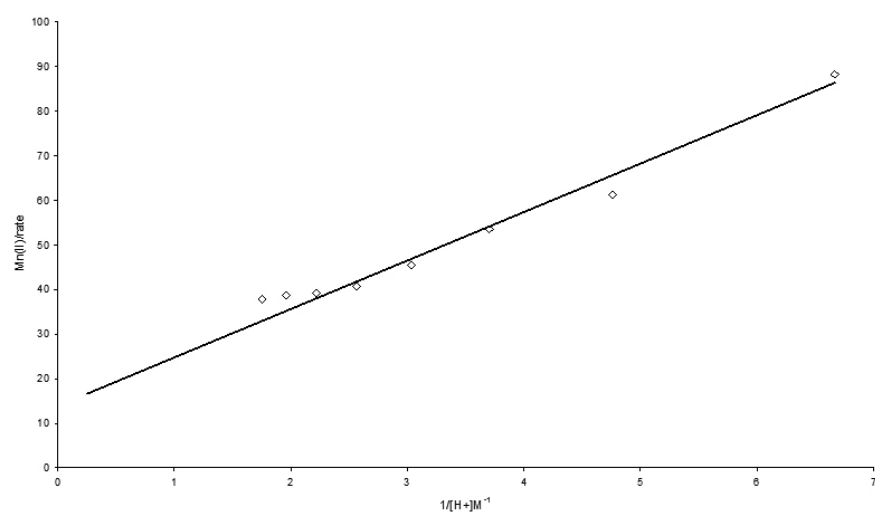

Fig.VII. plots of $\mathrm{Mn}(\mathrm{II})_{\mathrm{T}} /$ rate against $1 /\left[\mathrm{H}^{+}\right]$for arabinose at $40^{\circ} \mathrm{C}$. [arabinose $]=0.01 \mathrm{M}[\mathrm{V}(\mathrm{V})]=1 \times 10^{-3} \mathrm{M},\left[\mathrm{MnCl}_{2}\right]=6 \times 10^{-4} \mathrm{M} ;[\mathrm{KCl}]=$ $5 \times 10^{-4} \mathrm{M} ;\left[\mathrm{NaClO}_{4}\right]=0.1 \mathrm{M}$

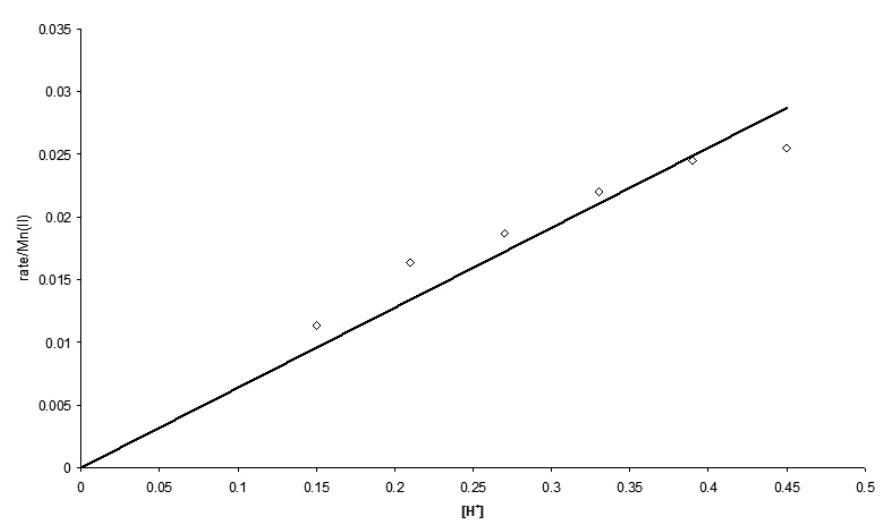

Fig.VIII. Plots of rate/Mn(II) $)_{\mathrm{T}}$ against $\left[\mathrm{H}^{+}\right]$for arabinose at $40^{\circ} \mathrm{C}$ : [arabinose $]=0.01 \mathrm{M},[\mathrm{V}(\mathrm{V})]=1 \times 10^{-3} \mathrm{M},\left[\mathrm{MnCl}_{2}\right]=6 \times 10^{-4} \mathrm{M} ;[\mathrm{KCl}]=5 \times 10^{-4} \mathrm{M}$; $\left[\mathrm{NaClO}_{4}\right]=0.1 \mathrm{M}$

For Xylose the values obtained from the above (fig.I and III) plots of Mn (II)/rate against $1 /[\mathrm{S}]$ and $\mathrm{Mn}(\mathrm{II}) /$ rate against $\left.1 / \mathrm{H}^{+}\right]$respectively were $2.123 \mathrm{moldm}^{-3} \mathrm{~s}^{-1}$ and $0.0483 \mathrm{moldm}^{-3} \mathrm{~s}^{-1}$, the value $\mathrm{k}_{3}$ obtained from the intercepts of the above plots are $0.308 \mathbf{s}^{-1}$ and $0.033 \mathrm{~s}^{-1}$ respectively.

A similar plot was also made for Arabinose which also support the validity of the equation (fig. V and VII) and the values of the plot were found to be 0.416 moldm $^{-3} \mathrm{~s}^{-1}$ and 0.092 moldm $^{-3} \mathrm{~s}^{-1}$ and the value of $\mathrm{k}_{3}$ obtained from the intercepts of the above plots are $0.280 \mathrm{~s}^{-1}$ and $0.072 \mathrm{~s}^{-1}$

At low concentration of $[\mathrm{S}]$ and $\left[\mathrm{H}^{+}\right]$, the integral; $1 \gg \mathrm{K}_{2} \mathrm{~K}_{1}[\mathrm{~S}]\left[\mathrm{H}^{+}\right]$will be valid, so the rate $=\mathbf{k}_{3} \mathbf{K}_{2} \mathbf{K}_{1}[\mathbf{S}]\left[\mathbf{H}^{+}\right]\left[\mathbf{V O}_{2}^{+}\right]$;

The graph of rate/Mn(II) vs. [S] and a graph of rate/Mn(II) vs. $\left[\mathrm{H}^{+}\right]$were plotted the values of $\mathrm{k}_{3} \mathrm{~K}_{2} \mathrm{~K}_{1}$ obtained for xylose (fig. II and IV) are 2.045 moldm ${ }^{-3} . \mathbf{s}$ and 0.040 moldm $^{-3} . \mathbf{s}$ respectively. A similar plot for arabinose gives the values of (fig. VI and VIII) $\mathrm{k}_{3} \mathrm{~K}_{2} \mathrm{~K}_{1}$ to be $0.342 \mathrm{moldm}^{-3} . \mathrm{s}$ and 0.064 moldm ${ }^{-3}$.s respectively. The table $\mathrm{V}$ and $\mathrm{VI}$ below gives the value of $\mathrm{k}_{3} \mathrm{~K}_{2} \mathrm{~K}_{1}$ and $\mathrm{k}_{3}$ obtained from the various plots above.

From the plots based on the two equations reveals that the values of $\mathrm{k}_{3} \mathrm{~K}_{2} \mathrm{~K}_{1}$ and $\mathrm{k}_{3}$ are in good agreement with one another. These results support the validity of the rate law equation.

$$
\mathrm{Mn}(\mathrm{II})_{\mathrm{T}} * \frac{1}{\text { Rate }}=\frac{1}{\mathrm{k}_{3} \mathrm{~K}_{2} \mathrm{~K}_{1}[\mathrm{~S}]\left[\mathrm{H}^{+}\right]\left[\mathrm{VO}_{2}^{+}\right]}+\frac{1}{\mathrm{k}_{3}\left[\mathrm{VO}_{2}^{+}\right]}
$$

Table V: Values of $\mathrm{k}_{3} \mathrm{~K}_{2} \mathrm{~K}_{1}$ obtained from the various plots below;

\begin{tabular}{|c|c|c|c|c|}
\hline Sugars & $\begin{array}{c}\text { Mn(II)/rate } \\
\text { vs. 1/[S] }\end{array}$ & $\begin{array}{c}\text { Mn(II)/ } \\
\text { rate vs. 1/ } \\
{\left[\mathbf{H}^{+}\right]}\end{array}$ & $\begin{array}{c}\text { Rate/ } \\
\text { Mn(II) } \\
\text { vs.[S] }\end{array}$ & $\begin{array}{c}\text { Rate/Mn(II) } \\
\text { vs. }\left[H^{+}\right]\end{array}$ \\
\hline Xylose & 2.123 & 0.0483 & 2.045 & 0.040 \\
\hline Arabinose & 0.416 & 0.092 & 0.342 & 0.064 \\
\hline
\end{tabular}

Average linear regression coefficients, $r \geq 0.9$, were observed for the parameters.

Table VI: Values of $\mathrm{k}_{3}$ were obtained from the plots of $\mathrm{Mn}(\mathrm{II}) /$ rate versus $1 /[\mathrm{S}]$ and $\mathrm{Mn}(\mathrm{II}) /$ rate

\begin{tabular}{|c|c|c|}
\hline Sugars & Mn(II)/rate vs. 1/[S] & $\begin{array}{c}\text { Mn(II)/rate vs. 1/ } \\
{\left[\mathbf{H}^{+}\right]}\end{array}$ \\
\hline Xylose & 0.308 & 0.033 \\
\hline Arabinose & 0.280 & 0.072 \\
\hline
\end{tabular}

Average linear regression coefficients, $r \geq 0.9$, were observed for the parameters.

\section{CONCLUSION}

The conclusions drawn, from the spectral information and from the observed kinetic data $i$ The observed negative entropy of activation for the oxidation of both sugars supports the fact that a complex is formed between the [sugar], [V(V)] and $\mathrm{Mn}(\mathrm{II})$.

ii The value of activation energy (Ea) of the catalyzed and the uncatalysed paths is consistent with the accepted view that a slow reaction would require a higher energy of activation and also that the reactions is catalysed by $\mathrm{Mn}(\mathrm{II})$ under the reaction conditions.

\section{REFERENCES}

1. E.O. Odebunmi, S.A. Iwarere, S.O. Owalude, Int. Journal Chem, 13, 167, (2006).

2. E.O. Odebunmi, R. Marufu Nigerian Journal of Science 33, 133, (1999

3. K.K. Sen Gupta, U. Chatterjee, Carbohydrate Research,126, 321,(1984)

4. R. Tripathi, S.K. Upadhyay, Int. J. Chem. Kinet. 36, 441, (2004).

5. A.K. Singh, J. Srivastava, S. Rahmani, V. Singh, Carbohydr. Res.341,397,(2006).

6. A.K. Singh, D. Chopra, S. Rahmani, B. Singh, Carbohydr. Res. 314, 151, (1998)

7. A.K. Singh, A. Singh, R. Gupta, M. Saxena, B. Singh, Trans. Met. Chem.17, 413, (1992).

8. A.K. Singh, N. Chaurasia, S. Rahmani, J. Srivastava, A.K. Singh, J. Chem. Res. 304, (2005).

9. Z. Khan, P.S.S. Babu, Kabir-ud-Din, Carbohydr.Res. 339,133,(2004).

10. A. Mohammed, I. Maqsood, A.Z. SyedMisbah, K. Zaheer, Research Letters in Physical Chemistry, Article ID 82901, (2007).

11. C. H. Graham, S.H. John "Chemistry in Context" $8^{\text {th }}$ edition, UK,291, (1995).

12. F. Feigl, Spot Tests in Organic Analysis, Elsevier, New York, 368,1960.

13. R.N. Mehrotra J. Chem Soc. 642, (1968)

14. T.A. Turney "Oxidation Mechanism" Butterworth's, London, 35, (1965).

15. W.A. Waters, J.S. Littler, J. Chem. Soc., 3014, (1959).

16. W. Huaisheng, Z. Aimei, Microchemical Journal, 57,2,218, (1997).

17. L. Zucker, L.P. Hammet, Journal of the American Chemical Society",61, 2791, (1939).

18. A.A. Frost, R.G. Pearson, Kinetics and mechanism, Wiley \& sons New York, 123-159, (1970).

19. R.M., Mulla, G.C. Hiremath, S.T., Nandibewoor, J. Chem Sci.,117,33 (2005).

20. Y. Shechter, A. Shisheva, Endeavour 17, 27, (1993).

21. R. Wever and K. Kustin, Adv. Inorg. Chem. 35, 81, (1990).

22. A.S. Ogunlaja, E.O. Odebunmi, S.O. Owalude. Pacific Journal of Science and Technology. 10, 451, (2009). 